\title{
Meditation as a Psychotherapeutic Tool
}

\section{Медитація як психотерапевтичний інструмент}

\author{
Mykola Mazykin \\ Head of PO «European Halychyna», Organizer of the Project \\ «Neuroculture», Lviv (Ukraine) \\ ORCID ID: https://orcid.org/0000-0002-8925-5872 \\ E-mail: mazikinmikola@gmail.com

\section{Микола Мазикін} \\ Голова ГО «Європейська Галичина», керівник проекту \\ «Нейрокультура», м. Львів (Україна)
}

\section{ABSTRACT}

The article presents the results of an implementation of meditations into the Ukrainian practice of psychocorrection of human mental disorders and an adaptation of meditations to the socio-cultural features of Ukraine.

The modern understanding of the term "meditation" and the possibility of using neurointerfaces for training and daily practice of meditations are considered in the study. The expediency of studying the electrical activity of the brain in laboratory and field conditions has been determined.

The aim of the article is systematization of the theoretical, methodological and practical principles of the possibility to use meditations to preserve the mental health of Ukrainian citizens.

Methods and techniques of the research. The EMOTIV Epoc+ mobile 14 channel neurointerface was used to study the meditation. We have used EEG monitoring software to visualize brain electrical activity and to get transformed EEG indicators in the form of basic cognitive-emotional indicators: MyEMOTIV,

Address for correspondence, e-mail: kpnu_lab_ps@ukr.net Copyright: (C) Mazykin Mykola

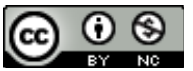


EMOTIV Brain Activity Map and EmotivPRO. The empirical sample was 75 veterans.

Results. The influence of meditations on the mental condition of a human has been shown. It has been shown that happiness is a trained skill through daily meditation practice. Adaptation of secular meditations for the correction of post-traumatic stress disorder is presented within the cognitive-behavioral therapy. The changes in central nervous system activity while meditative session are characterized, they manifest themselves as intensified activity of integrative brain system, increased awareness and control of cognitive processes, emotional sphere and functional states of mind among 75 veterans.

Conclusions. Summarizing the findings and interpreting the cognitiveemotional indicators, it was concluded that implementation of meditations into the practice of psychocorrection of human mental disorders was efficient. The author has proved that the main criterion for the classification of the process of meditation should be the EEG patterns of human cognitive activity more than his/her behaviour. It is recommended to use the neurointerface in the course of psychocorrection of mental disorders.

Key words: meditation, personality, prefrontal cortex, happiness, mental disorders, psychocorrection.

\section{Вступ}

У наш час, насичений соціальними трансформаціями, збройним конфліктом, економічним занепадом, люди дуже часто стикаються зі стресом. Це призводить до того, що наша країна посідає перше місце у Європі за поширенням психічних розладів. Статистика невтішна, оскільки в Україні 1,2 млн мешканців мають психічні розлади, а кожен третій громадянин нашої країни страждає від різних нервово-психічних розладів. Більш того, інвалідизація від психічних захворювань зайняла друге місце серед усіх захворювань. Не варто також забувати про наближення епідемії посттравматичного стресового розладу у ветеранів збройного конфлікту на Сході країни. Тому необхідно знайти ефективні рішення, що дадуть змогу вберегти психічне здоров'я громадян України.

(C) Mazykin Mykola

DOI (article): https://doi.org/10.32626/2227-6246.2020-47.141-158 
DOI: https://doi.org/10.32626/2227-6246.2020-47 2020. ВиПУСК 47

Змінити обставини контексту, в якому перебувають люди, ми, психологи, не завжди можемо, та це й не входить у наші професійні компетенції, а ось змінити ставлення i сприйняття особистості до стресогенних чинників ми можемо. Існує багато тренінгів із вироблення комплексу фіксованих дій на певний чинник-стресор, проте життя дуже непередбачуване і до всіх ситуацій підготуватися не можливо. Тому виглядає дивним підхід, коли психолог виробляє в індивіда навик долати стрес у одних ситуаціях, а при цьому нехотячи виробляється безпорадність в інших психотравмуючих ситуаціях. Очевидно, що такий підхід потребує перегляду і заміни на більш конструктивне рішення.

Аналіз попередніх досліджень показав, що у західній культурі вирішення цієї проблеми було здійснено запозиченням ментальних тренувань зі Сходу з подальшою їх адаптацією до соціокультурних особливостей людей: медитації тибетського буддизму Rinpoche i Tworkov (Rinpoche \& Tworkov, 2014); медитативна нейробіологія Davidson i Begley (Davidson \& Begley, 2012); нейронаука щастя Hanson i Mendius (Hanson \& Mendius, 2009); антистрес-медитації Penman i Burch (Penman \& Burch, 2013). Ці ментальні тренування грунтуються на управлінні функціями та психічними станами особистості за допомогою концентрації уваги, сили волі, аналітики тощо.

Проте цьому передував грандіозний проект інституту «Розум і життя» (проект «Медитативна нейробіологія», 2000) разом із 20-ма провідними університетами США (Davidson \& Begley, 2012; Rinpoche \& Tworkov, 2014).

Існує величезний масив беззаперечних даних про вплив медитацій не лише на мозкову діяльність, зміну поведінки, корекцію кров'яного тиску, а й на зміни метаболізму та лікування психічних і соматичних розладів.

Кількість осіб, які практикують медитації, у світі зростає щороку (Tarrant, 2017). Більш того, з'явилася ціла індустрія, що створює прилади - нейроінтерфейси та програм(C) Mazykin Mykola DOI (article): https://doi.org/10.32626/2227-6246.2020-47.141-158 
DOI: https://doi.org/10.32626/2227-6246.2020-47

не забезпечення й інтерактивне навчання, які дозволяють правильно виконувати медитативні техніки.

В Україні медитації поширюються центрами оздоровлення у рамках духовного розвитку, дхармічними релігійними організаціями, а також використовуються для профілактики девіантної поведінки.

Виокремлено невирішені раніше частини загальної проблеми, а саме - не можна здійснити впровадження цих ментальних тренувань ні з культури Сходу, ні з культури Заходу, адже Україна знаходиться на перетині цих культур, i у цьому плані не є еклектичною, а неповторною та самобутньою культурою з великою цивілізаційною історією, а також країною, яка зазнала сильних трагічних соціальних потрясінь за останні століття. Тому питання застосування медитації як психотерапевтичного інструменту потребує подальшого та всебічного вивчення.

Мета статті - систематизувати теоретико-методологічні й практичні засади можливостей застосування медитацій для збереження психічного здоров'я громадян України.

\section{Завдання статті}

Реалізація вищезазначеної мети конкретизується через такі завдання:

1) розглянути історію розвитку медитацій;

2) висвітлити види медитацій;

3) грунтовно проаналізувати психотерапевтичний вплив медитацій на особистість і мозок людини;

4) представити власний досвід застосування медитацій;

5) визначити напрямки подальшого впровадження медитацій, а також нейротехнологій, необхідних для медитативної практики.

\section{Методи та методики дослідження}

Для досягнення мети дослідження застосовувалися загальнонаукові методи теоретичного й емпіричного дослі(C) Mazykin Mykola

DOI (article): https://doi.org/10.32626/2227-6246.2020-47.141-158 
дження: аналіз, порівняння й узагальнення інформації 3 фахової літератури, апробація медитацій як психотерапевтичного інструменту. Дослідження ефективності медитацій у рамках когнітивно-поведінкової терапії проводилося впродовж 2018-2019 pр. У дослідженні взяли участь 75 чоловіків-ветеранів віком 25-45 років із добровольчих батальйонів, які повернулися з війни з посттравматичним стресовим розладом. Дослідження проводилося під час волонтерського проекту «Нейрокультура» від ГО «Європейська Галичина».

Для діагностики посттравматичного стресового розладу та супутніх психічних розладів використовували методики: PCL-C - Контрольний список симптомів Посттравматичного стресового розладу; ACSS-FAD - Шкала набутої здатності до самогубства та відсутності побоювання смерті; Loneliness Scale - Шкала самотності та соціальної ізоляції; ASSIST Опитувальник ВООЗ для скринінгу на проблеми з алкоголем, тютюном і наркотиками; PSQ - Піттсбурзький індекс якості сну. Ці методики давали нам змогу визначати важкість перебігу й адекватно вибудовувати психотерапію. Крім того, для підвищення ефективності медитацій ми використовували нейроперсонологію Tkach (2018), що дозволяло нам індивідуально підбирати співвідношення цих трьох медитацій для кожного ветерана.

Для виявлення емоційних i когнітивних показників діяльності мозку під час навчання медитацій використовували 14-канальний нейроінтерфейс EMOTIV Epoc+ i програмне забезпечення для картографування мозку й моніторингу процесу, МуEMOTIV, EMOTIV Brain Activity Map та EmotivPRO.

\section{Результати та дискусії}

Перші писемні згадки про медитації знаходимо у Ведах (Everly \& Lating, 2002). Термін «медитація» походить від латинського слова meditatio (розмірковування), який бере початок від дієслова meditari, що означає «обдумува-

(C) Mazykin Mykola

DOI (article): https://doi.org/10.32626/2227-6246.2020-47.141-158 
ти, мисленнєво споглядати» тощо. Cunningham i Egan зазначають, що цей термін у європейській культурі з'явився з Біблії, а саме слово «хага», що означає «розмірковувати, споглядати, шепотіти», з івриту було перекладено латиною як meditatio (Cunningham \& Egan, 1996). Згодом під час перекладу духовних праць Сходу деякі терміни, зокрема, із санскриту «дx'яна» (dhyai), 3 китайської «чань» (chan), з японської «дзен» (zen), були перекладені як meditation. Аналіз дефініцій у енциклопедичних словниках дає підстави стверджувати, що зараз до медитацій відносяться духовні практики не лише індуїзму, буддизму, йоги, а також практики з античної філософії - піфагоризм, платонізм і неоплатонізм (філософський екстаз), ісламський суфізм (практика зікр, суть якої полягає у повторені 99 імен Бога), єврейська Каббала, християнський ісихазм (практика повторення Ісусової молитви, екзерциція) та містико-аскетичні практики козаків-характерників (бойові психотехніки Спасу). Глибокий аналіз енциклопедичних словників показав, що до медитативних технік можна віднести дещо 3 українського фольклору, а саме пісні, у яких повторюється текст, і їхнє виконання передбачає ритмічне погойдування та зосередження на внутрішньому стані (відчуття всередині організму, внутрішні образи, емоції тощо). В Українському радянському енциклопедичному словнику (1967 р., том 2) медитацію розглядають як форму філософської лірики, яка притаманна сентименталістам і романтикам у розмірковуванні про життя та його сенс. Медитація як психотерапевтичний засіб присутня у психоаналізі Юнга (Gabbard, Litowitz, \& Williams, 2012). Хочемо зазначити, що за основу класифікації необхідно брати не зовнішню схожість у поведінці індивіда під час медитації: усамітнення, релаксація, зосередження тощо, а ЕЕГ-патерни когнітивної діяльності, характерні для медитацій.

На сучасному етапі розвитку психології під медитацією розуміють ментальні (психічні) вправи, що використовують(c) Mazykin Mykola

DOI (article): https://doi.org/10.32626/2227-6246.2020-47.141-158 
ся у духовних, релігійних та оздоровчих практиках. Інколи під медитацією розуміють особливі психічні стани (змінені стани свідомості), що виникають у процесі медитативних ментальних тренувань для розслаблення та підсилення відчуття благополуччя. Усе рідше під медитацією розуміють ï̈ первинний релігійно-культурний зміст, а саме внутрішнє зосередження у процесі поглибленого розмірковування над духовною істиною з одночасним відволіканням уваги індивіда від зовнішніх (звуки, освітлення, об’єкти зовнішнього світу тощо) і внутрішніх (емоційний неспокій, відволікаючі думки тощо) подразників (Tarrant, 2017).

Очевидно, що різноманіття дефініцій медитації зумовлено різними видами медитацій і різними психічними проявами. Ми не розглядатимемо медитації у духовних і релігійних практиках, а зосередимося винятково на світських медитаціях як психотерапевтичних інструментах.

Праця «The Relaxation Response» вважається першою науковою апробацією медитації для зменшення впливу стресу на людину в повсякденному житті та професійній діяльності. Крім того, Benson i Klipper вивчали вплив медитації на здоров'я людини (Benson \& Klipper, 1974).

Розвиток методів нейровізуалізації та фіксації еклектичної активності мозку дозволив об'єктивно вивчити зміни у мозку при різних медитаціях. Зокрема, Davidson i Begley (Davidson \& Begley, 2012) установили, що люди з підвищеною активністю у правій півкулі мозку потребують значно більше подразників, щоб отримати задоволення. На їхню думку, міжпівкульна збалансована активність є «точкою відліку» для суб’єктивного відчуття щастя. Коли людина пережила позитивні емоції, відбувається активація лівої півкулі мозку, а коли негативні - активація правої. Зрозуміло, що згодом міжпівкульна активність повернеться до «точки відліку» суб'єктивного відчуття щастя. У Davidson i Begley виникла ідея перевірити, чи можливо завдяки медитації свідомо управляти міжпівкульною асиметрією для утриман-

(C) Mazykin Mykola

DOI (article): https://doi.org/10.32626/2227-6246.2020-47.141-158 
ня довготривалого відчуття щастя. Перевірка припущення здійснювалася на студентах і монахах-майстрах медитації. Монахи навчили студентів медитації співпереживання. Виявилося, що у студентів до навчання активність була у правій півкулі мозку, а після навчання розподілилася в обох півкулях. Тоді як у монахів до медитацій активність мозку була в обох півкулях, а після медитації активнішою стала ліва півкуля мозку. Цей експеримент показав, що відчуття співпереживання і щастя можна натренувати.

Schwartz i Begley (Schwartz \& Begley, 2002) виявили, що під час глибокої медитації активізується префронтальна кора мозку, а щоденна практика медитації упродовж десяти тижнів покращує психічний стан у пацієнтів з обсесивно-компульсивним розладом. Penman i Burch (Penman \& Burch, 2013) розробили усвідомлену антистрес-медитацію для терапії депресії та підвищення стійкості людей до стресу. Щоденна практика медитації по 15 хв виробляє у людини навички контролю думок і емоцій. На сьогодні ця медитація визнана у Великій Британії на законодавчому рівні як лікувальна процедура.

Найпопулярнішою позою для медитації, завдяки кінематографу, є поза «лотос»- коли людина сидить із випрямленою спиною, закритими очима, дещо опущеною головою, ноги схрещені, руки розташовані на колінах долонями доверху, великий і вказівний пальці зімкнені. Проте на практиці рідко хто так медитує. Адже медитувати можна у будьякій позі та будь-якій діяльності, а об’єктом медитації може бути фізичний предмет, власні відчуття та ідеї. Найзручніше медитувати, сидячи на підлозі, коли під сідниці підкладено подушку висотою 20 см, або на скошеному до переду ослінчику (низький стільчик із нахилом поверхні для сидіння).

На сьогодні неможливо не згадати нейротехнології, що використовуються у медитативній практиці, - нейроінтерфейси - прилади, які підключають мозок до комп'ютера. Серед великого асортименту нейроінтерфейсів, на нашу екс(c) Mazykin Mykola

DOI (article): https://doi.org/10.32626/2227-6246.2020-47.141-158 
пертну думку, заслуговують на увагу: EMOTIV Insight (5-канальний), Muse (5-канальний), Neurosky (3-канальний) та EMOTIV Epoc+ (14-канальний). Усі ці нейроінтерфейси дуже швидко інсталюються на голові й швидко налаштовуються за допомогою програмного забезпечення для портативних комп'ютерів (смартфони і планшети). EMOTIV Insight є універсальним нейроінтерфейсом, який можна використовувати не лише для практики медитацій, а й для діагностики й управління приладами / програмами завдяки думці (ментальні команди). Крім того, він має інноваційне покриття на давачах, що дає змогу людині активно поводитися під час медитацій. Muse створений винятково для медитацій i вимагає спокійної поведінки. Neurosky подібний на EMOTIV Insight, проте поступається програмним забезпеченням, але його цілком достатньо для повсякденної медитативної практики. EMOTIV Epoc+ перевершує EMOTIV Insight за кількістю давачів, проте вимагає більше часу для інсталяції. Ідеальним варіантом буде створення у близькому майбутньому мініатюрного нейроінтерфейсу у вигляді бездротових навушників. Це вже анонсовано компанією Neurable.

Для наукових досліджень медитації найкраще підходять у лабораторних умовах багатоканальні ЕЕГ і добре екрановане приміщення. У випадку дослідження медитацій у польових умовах (повсякденне життя, екстремальні умови, змагання, тренування тощо) найкраще підходять Wearable Sensing DSI-7 (7-канальний), Neuroelectrics ENOBIO 8 (8-канальний), B-Alert X 10 (10-канальний), EMOTIV Epoc+ (14-канальний), Neuroelectrics ENOBIO 20 (20-канальний), Wearable Sensing DSI 24 (24-канальний), Alert X 24 (24-канальний), Neuroelectrics ENOBIO 32 (32-канальний).

Ми на власній практиці переконалися, що найефективнішим способом є медитативна нейробіологія. Адже саме використання нейроінтерфейсу та професійного програмного забезпечення дало нам змогу здійснювати об'єктивну оцінку важкості психічного розладу, відслідковувати пере-

(C) Mazykin Mykola

DOI (article): https://doi.org/10.32626/2227-6246.2020-47.141-158 
DOI: https://doi.org/10.32626/2227-6246.2020-47 2020. випуск 47

біг психотерапії й робити прогноз. Дуже часто в житті люди декларують / повідомляють одну інформацію, а насправді на підсвідомому рівні відчувають і прагнуть зовсім до іншого. Яскравим прикладом слугує дослідження сучасних українських науковців С. Максименка, Б. Ткача, Л. Литвинчук і Л. Онуфрієвої (Maksymenko, Tkach, Lytvynchuk \& Onufriieva, 2019) підсвідомих реакцій виборців на політичну рекламу. Результати цього дослідження за 4 місяці до виборів абсолютно точно передбачили їх результати. Тому переконливо рекомендуємо використовувати нейроінтерфейси у психотерапії, оскільки без нейроінтерфейсу неможливо було б швидко виробляти навички самоконтролю та керованого відчуття щастя.

У нашому суспільстві надзвичайно популярними стали йога й інші східні системи духовної практики для оздоровлення. Водночас тривала історична присутність і брендування авраамічних релігій не дають можливості легко впровадити медитації в усіх сферах професійної діяльності та повсякденного життя людей. Проте ми спробували адаптувати до соціокультурних особливостей України медитації як психологічний інструмент у межах когнітивно-поведінкової терапії для ветеранів, які самостійно чи на прохання рідних / близьких зверталися до нас. Було використано три буддійські медитації: зосередженості, усвідомленості та співпереживання.

Медитація зосередження передбачає, що людина сконцентровує свою увагу на об'єкті / явищі. Це може бути будьщо: візуальні образи, звуки, запах, дихання, пульс. Важливим є вміння виробити навички утримувати увагу, помічати моменти відволікання та поновлювати увагу до об'єкта медитації. Процес відволікання і повернення уваги має чотири фази: вислизання уваги; усвідомлення відволікання; переорієнтація уваги; відновлення стійкої уваги. Методи нейровізуалізації дали змогу встановити, що у момент відволікання активними є дорзальна тім'яна ділянка, передклиння, (C) Mazykin Mykola

DOI (article): https://doi.org/10.32626/2227-6246.2020-47.141-158 
дорзальна поясна кора, медіальна префронтальна кора та латеральна ділянка скроневої кори мозку. У момент, коли в людини виникає усвідомлення відволікання, то підвищується активність острівцевої та передньої поясної кори мозку. Наголошуємо, що цей момент у медитації зосередження є головним навиком. Коли відбувається відволікання, то активними стають дорзолатеральна префронтальна кора та нижня тім'яна частка. Коли у медитуючого стійка увага, то наявна висока активність дорзолатеральної префронтальної кори мозку (Davidson et al., 2003; Kellawon, 2014; Apple, Fonseca \& Kokovay, 2016).

Медитація усвідомлення передбачає безперервне та максимальне сприйняття всіх подразників: зовнішнього світу, тілесних відчуттів і психічного стану. Важливо зазначити, що це не аналітична медитація: аналізувати нічого не потрібно, лише сприйняття та констатація сприйнятого. Така когнітивна діяльність спричиняє зниження активності острівцевої кори та мигдалеподібних тіл, що проявляється зниженням тривоги (Penman \& Burch, 2013; Rinpoche \& Tworkov, 2014).

Медитація співпереживання передбачає вироблення емпатійності до інших. Під час цієї медитації виникає підвищення активності у скронево-тім'яній ділянці та вентромедіальній лобовій корі (Hanson \& Mendius, 2009; Penman \& Burch, 2013; Rinpoche \& Tworkov, 2014).

Iз нашого досвіду виявилося, що найлегше ветеранам дається медитація концентрації та усвідомлення, а найважче - медитація співпереживання. I це не дивно, адже їм тривалий час доводилося бути дуже уважними до всього та використовувати інструментальну агресію задля захисту нашої країни. Тому суспільство просто зобов'язане докласти всіх зусиль задля повернення в родини ветеранів втраченого на війні відчуття щастя і радості.

С. Максименко зазначає, що у науковому дослідженні особистості вибір методу має вирішальне значення у побудо(C) Mazykin Mykola DOI (article): https://doi.org/10.32626/2227-6246.2020-47.141-158 
ві теоретичної конструкції трансформації зміни особистості (Maksymenko, 2015).

Отже, першим етапом психотерапії було знайомство та налагодження конструктивної комунікації у тій світоглядній системі, що властива клієнту. Ми не розпитуємо про події війни, не даємо оціночного судження, а винятково зосереджуємося на знайомстві та вивченні лінгво-когнітивних конструктів, які найчастіше присутні у лексиці.

Другим етапом була діагностика психічних розладів, пов'язаних із війною, а саме: який рівень прояву посттравматичного стресового розладу, схильність до суӥцидальної поведінки, наскільки ветеран самотній і зазнає соціальної ізоляції, наявність хімічних адикцій (алкоголь, тютюн i наркотики) і пов'язані з цим наслідки, а також вивчалася якість сну. Це давало психологам підстави присвоїти кожному ветерану індивідуальний профіль і орієнтуватися в тому, над чим працювати в першу чергу.

Наступним етапом була нейропсиходіагностика за Б. Ткачем для встановлення нейроперсонологічного типу ветерана (Tkach, 2018). Цей момент є ключовим, адже дає змогу зрозуміти суть психологічної проблеми, шляхи іï вирішення, індивідуально підібрати співвідношення медитацій для кожного ветерана.

Третій етап роботи передбачав створення ілюзії впевненості та позбавлення почуття провини у ветерана за вчинки у минулому. Для цього використовується бесіда із застосуванням символічної та традиційної логіки. Необхідно вилучити зі свідомості доктрину гріха. Найкраще підходить групова робота для повернення відчуття реальності, шляхом позбавлення спотвореного мислення. Це дає змогу зменшити частоту страшних сновидінь і значно покращити якість сну. Нормалізацію структури сну та співвідношення фаз сну оцінювали завдяки фітнес-браслету і додаткам на смартфоні.

Четвертий етап - це медитативна практика. Перші сесії є короткими, по 10 секунд, з обов'язковим використанням (c) Mazykin Mykola

DOI (article): https://doi.org/10.32626/2227-6246.2020-47.141-158 
нейроінтерфейсу. Аналізуючи мозкову активність під час медитації, ми, психологи, в режимі реального часу виявляємо, що саме важко дається у виконанні ментальних вправ. За кожним клієнтом ведеться журнал результативності терапії та процесу вироблення навичок свідомо керувати відчуттям щастя й усвідомленої поведінки. Ефективність наочно бачимо завдяки ЕЕГ-моніторингу.

П'ятий етап терапії полягав у виробленні навичок ефективно опрацьовувати негативну інформацію. Критерієм ефективності було повернення навиків структурування часу, резильєнтність і контроль завищеного почуття справедливості.

Таблищя 1

Трансформація основних когнітивних і емоційних показників серед ветеранів до та після психокорекції

\begin{tabular}{|l|c|c|c|c|c|c|}
\hline & Стрес & Взаємодія & Інтерес & $\begin{array}{c}\text { Хвилю- } \\
\text { вання }\end{array}$ & $\begin{array}{c}\text { Концент- } \\
\text { рація }\end{array}$ & $\begin{array}{c}\text { Релакса- } \\
\text { ція }\end{array}$ \\
\hline До & 45,83 & 52,73 & 49,76 & 43,04 & 44,25 & 31,46 \\
\hline Після & 42,21 & 59,15 & 62,23 & 46,55 & 51,69 & 48,28 \\
\hline $\mathrm{p}$ & $\mathrm{p} \leq 0,05$ & $\mathrm{p} \leq 0,001$ & $\mathrm{p} \leq 0,01$ & $\mathrm{p} \leq 0,05$ & $\mathrm{p} \leq 0,05$ & $\mathrm{p} \leq 0,001$ \\
\hline
\end{tabular}

Коротко розкриємо суть основних когнітивно-емоційних показників, сформованих біометричною компанією «EMOTIV», які вираховуються на базі специфічних ЕЕГ-патернів мозку (Insight, 2017).

Стрес відображає комфорт і дискомфорт досліджуваного.

Взаєлодія відображає наскільки досліджуваний залучений до того, що робить чи переживає.

Інтерес відображає цікавість досліджуваного до стимулу.

Хвилювання відображає прояв емоційної реакції (ажіотаж).

Концентрація відображає зосередженість на подразнику.

Релаксація відображає психічний спокій.

3 отриманих аналітичних даних (табл. 1) зрозуміло, що наявні характерні зміни в роботі центральної нервової сис-

(C) Mazykin Mykola

DOI (article): https://doi.org/10.32626/2227-6246.2020-47.141-158 
теми після медитативного сеансу, які проявляються посиленою діяльністю інтегративної системи мозку, підвищенням обізнаності та контролю когнітивних процесів, емоційної сфери і функціональних станів психіки у ветеранів.

На даний момент не зафіксовано жодного рецидиву посттравматичного стресового розладу і спостерігається прийнятна ресоціалізація. Хотіли б зробити уточнення, що хімічні адикції не вдається повністю подолати, лише досягається кероване вживання у дозволених суспільством ситуаціях (застілля, вечірки тощо). Також повільному процесу відмови від алкоголю і тютюну сприяють соматичні хвороби, псування зубів і травми, набуті на війні.

Ресоціалізація реалізується не за принципом повернення до попереднього місця роботи чи діяльності, а ветерани здобувають нову освіту, або ж утілюють свої мрії, які у силу певних життєвих обставин не вдавалося здійснити раніше. Зміна світогляду та переосмислення життєвих цінностей i вироблення «власної філософської позиції, спрямованої на самопізнання й гіперпросоціальну діяльність, спочатку з подивом сприймається рідними та близькими. Проте родичі, долучившись до медитативної практики, також починають змінювати своє ставлення до світу, до оточуючих і самих себе. Медитація стає звичним буденним явищем для таких сімей.

Вищезазначений комплекс психотерапевтичної роботи реалізується цілою бригадою психологів упродовж чотирьох днів, а також періодично (1 раз на місяць) здійснюється дистанційний патронаж завдяки скайп-зв'язку. Згодом ветерани самі час від часу телефонують і повідомляють про якісні зміни у їхньому житті та перебіг ресоціалізації.

\section{Висновки}

Теоретико-методологічний аналіз засвідчив можливості застосування світських медитацій для збереження психічного здоров'я громадян України. Присутність медитацій у різ(c) Mazykin Mykola

DOI (article): https://doi.org/10.32626/2227-6246.2020-47.141-158 
них культурах, зокрема й українській, відкриває перспективи для впровадження медитацій у різні сфери діяльності людини.

В основу критеріїв визначення медитації та класифікації ї̈ різновидів необхідно брати ЕЕГ-патерни, а не поведінкові ознаки.

Висвітлення психотерапевтичного впливу медитацій зосередженості, усвідомленості та співпереживання на особистість доводить високу ефективність психотерапії посттравматичного стресового розладу у ветеранів та економічну доцільність розвитку медитативної нейробіології в Україні.

Розгляд сучасного стану проблеми впровадження медитацій указує на обов'язкове використання нейроінтерфейсів для навчання та самостійної практики медитацій.

Перспективи подальшого дослідження полягають у продовженні розробки й адаптації медитацій до соціокультурних особливостей України. В ідеалі було б доцільно створити цілий додаток, який би інтегрував показники від нейроінтерфейсу і фітнес-браслету, а також автоматизував психодіагностику та нейропсиходіагностику. Це б значно спростило роботу для психолога і дало змогу передбачати можливі рецидиви.

\section{References}

Apple, D. M., Fonseca, R. S., \& Kokovay, E. (2016). The role of adult neurogenesis in psychiatric and cognitive disorders. Brain Res., 1655, Jan. 15, 270-276. DOI 10.1016/j.brainres.2016.01.023.

Benson, H., \& Klipper, M. Z. (1974). The Relaxation Response. New York : William Morrow and Company, Inc.

Cunningham, L. S., \& Egan, K. J. (1996). Christian spirituality: themes from the tradition. Mahwah : Paulist Press.

Davidson, R. J., \& Begley, S. (2012). The Emotional Life of Your Brain: How Its Unique Patterns Affect the Way You Think, Feel, and Liveand How You Can Change Them. New York : Hudson Street Press.

Davidson, R., Kabat-Zinn, J., Schumacher, J., Rosenkrantz, M., Muller, D., Santorelli, S., ... \& Sheridan, J. F. (2003). Alterations in

DOI (article): https://doi.org/10.32626/2227-6246.2020-47.141-158

(C) Mazykin Mykola 
brain and immune function produced by mindfulness meditation. Psychosomatic Medicine, 65 (4), 564-570.

Everly, G. S., \& Lating, J. M. (2002). A clinical guide to the treatment of human stress response. New York : Springer-Verlag.

Gabbard, G. O., Litowitz, B. E., \& Williams, P. (2012). Textbook of Psychoanalysis (2 ed.). Arlington : American Psychiatric Publishing, Inc.

Hanson, R., \& Mendius, R. (2009). Buddha's Brain: The Practical Neuroscience of Happiness, Love, and Wisdom. Oacland : New Harbinger Publications, Inc.

Insight (2017). Emotiv. Retrieved from https://www.emotiv.com/insight. Kellawon, G. A. (2014). Yoga Meditations. Bloomington : Balboa Press.

Maksymenko, S. D. (2015). Genesis of Personality Existence: monography. Montreal : Accent Graphics Communication.

Maksymenko, S., Tkach, B., Lytvynchuk, L., \& Onufriieva, L. (2019). Neuro-Psycholinguistic Study of Political Slogans in Outdoor Advertising. PSYCHOLINGUISTICS, 26 (1), 246-264. Retrieved from https://doi.org/10.31470/2309-1797-2019-26-1-246-264.

Penman, D., \& Burch, V. (2013). Mindfulness for Health: A Practical Guide to Relieving Pain, Reducing Stress and Restoring Wellbeing. London : Little, Brown Book Group.

Rinpoche, Y. M., \& Tworkov, H. (2014). Turning Confusion into Clarity: A Guide to the Foundation Practices of Tibetan Buddhism. Boston \& London : Slow Lion.

Schwartz, J., \& Begley, S. (2002). The mind and the brain: Neuroplasticity and the power of mental force. New York : Regan Books.

Tarrant, J. (2017). Meditation Interventions to Rewire the Brain: Integrating Neuroscience Strategies for ADHD, Anxiety, Depression \& PTSD. Eau Claire : PESI Publishing \& Media.

Tkach, B. (2018). Neuropsychological features personalities with deviant behavior. Fundamental and applied researches in practice of leading scientific schools, 27 (3), 201-206.

\section{Мазикін Микола. Медитація як психотерапевтичний інструмент}

\section{АНОТАЦІЯ}

Обгрунтовано необхідність упровадження медитацій в українську практику психокорекції психічних розладів людини та представлено адаптацію медитацій до соціокультурних особливостей України. Розглянуто сучасне розуміння терміна "медитація» і можливість застосування нейроінтерфейсів для навчання та щоденної практики медитацій. Окреслено (C) Mazykin Mykola

DOI (article): https://doi.org/10.32626/2227-6246.2020-47.141-158 
DOI: https://doi.org/10.32626/2227-6246.2020-47 2020. ВИПУСК 47

дочільність дослідження електричної активності мозку в лабораторних і польових умовах.

Метою статmі є систематизація теоретико-методологічних $i$ практичних засад можливості застосування медитацій для збереження психічного здоров'я громадян України.

Для вивчення медитації було використано мобільний 14-канальний нейроінтерфейс EMOTIV Eрос+. Також було використано програмне забезпечення для ЕЕГ-моніторингу та візуалізації електричної активності мозку, а також для отримання трансформованих ЕЕГ-патернів у вигляді основних когнітивно-емоційних показників: MуEMOTIV, EMOTIV Map Brain Activity Map i EmotivPRO. Вибірка становила 75 ветеранів.

Показано вплив медитацій на психічний стан людини. Продемонстровано, що відчуття щастя є тренованим навиком завдяки щоденній практиці медитацій. У межах когнітивно-біхевіоральної терапії представлено адаптацію світських медитацій для корекції посттравматичного стресового розладу. Виявлено характерні зміни в роботі центральної нервової системи під час медитативного сеансу, які проявляються посиленою діяльністю інтегративної системи мозку, підвищенням обізнаності та контролю когнітивних прочесів, емочійної сфрери і функчіональних станів психіки у 75 ветеранів.

Узагальнюючи результати й інтерпретуючи когнітивно-емоційні показники, зроблено висновок про доцільність упровадження медитацій у практику психокорекції психічних розладів людини. Доведено, що основним критерієм класифікації процесу медитації мають бути ЕЕГ-патерни когнітивної діяльності людини, а не ії поведінка. Рекомендується використовувати нейроінтерфейс у прочесі психокорекції психічних розладів.

Ключові слова: медитація, особистість, префронтальна кора, щастя, психічні розлади, психокорекція.

\section{Мазыкин Николай. Медитация как психотерапевтический инструмент}

\section{АННОТАЦИЯ}

Обоснована необходимость внедрения медитаций в украинскую практику психокоррекции психических расстройств человека и представлено адаптацию медитаций к социокультурным особенностям Украины. Рассмотрены современное понимание термина «медитация» и возмож-

(C) Mazykin Mykola

DOI (article): https://doi.org/10.32626/2227-6246.2020-47.141-158 
ность применения нейроинтерфейсов для обучения и ежедневной практики медитаций. Определены целесообразность исследования электрической активности мозга в лабораторных и полевых условиях.

Целью статьи является систематизация теоретико-методологических и практических основ возможности применения медитаций для сохранения психического здоровья граждан Украины.

Для изучения медитации было использовано мобильный 14-канальный нейроинтерфейс ЕMOTIV Ерос+. Также было использовано программное обеспечение для мониторинга ЭЭГ и визуализации электрической активности мозга, а также для получения трансформированных ЭЭГ-паттернов в виде основных когнитивно-эмоциональных показателей: MyEMOTIV, EMOTIV Map Brain Activity Map и EmotivPRO. Выборка составила 75 ветеранов.

Показано влияние медитаций на психическое состояние человека. Продемонстрировано, что ощущение счастья является тренированным навыком благодаря ежедневной практике медитаций. В рамках когнитивно-бихевиоральной терапии представлено адаптацию светских медитаций для коррекции посттравматического стрессового расстройства. Выявлены характерные изменения в работе центральной нервной системы во время медитативного сеанса, которые проявляются усиленной деятельностью интегративной системы мозга, повышением осведомленности и контроля когнитивных процессов, эмоциональной сферы и функциональных состояний психики у 75 ветеранов.

Обобщив результаты и интерпретируя когнитивно-эмоциональные показатели, сделан вывод о целесообразности внедрения медитаций в практику психокоррекции психических расстройств человека. Доказано, что основным критерием классификации процесса медитации должны быть ЭЭГ-паттерны когнитивной деятельности человека, а не его поведение. Рекомендуется использовать нейроинтерфейс в процессе психокоррекции психических расстройств.

Ключевые слова: медитация, личность, префронтальная кора, счастье, психические расстройства, психокоррекция.

Original manuscript received January 02, 2019 Revised manuscript accepted January 25, 2020

(C) Mazykin Mykola

DOI (article): https://doi.org/10.32626/2227-6246.2020-47.141-158 